\title{
Stress and Performance of Elementary School Teachers of Southern Papua: A Survey Approach
}

\author{
Berlinda Setyo Yunarti ${ }^{1}$, Sandra Ingried Asaloei ${ }^{2}$, Paulina Wula ${ }^{1}$, Basilius Redan Werang, ${ }^{3}{ }^{*}$ \\ ${ }^{1}$ Sekolah Tinggi Katolik Santo Yakobus, Merauke, Indonesia \\ ${ }^{2}$ Universitas Sam Ratulangi, Manado, Indonesia \\ ${ }^{3}$ Universitas Musamus, Merauke, Indonesia \\ *Corresponding Author: lirang267@yahoo.co.id \\ Received December 13, 2019; Revised January 13, 2020; Accepted February 7, 2020
}

Copyright $\odot 2020$ by authors, all rights reserved. Authors agree that this article remains permanently open access under the terms of the Creative Commons Attribution License 4.0 International License

\begin{abstract}
This study aimed at describing the potential effect of teachers' work-related stress on their job performance in the elementary schools of Southern Papua, Indonesia. To attain this objective, we employed a quantitative approach using a survey research design. Two quantitative survey questionnaires using a four point Likert's scale were administered to 1062 teacher respondents which were incidentally drawn from amongst 3078 elementary schools' teachers of Southern Papua. Data were analyzed quantitatively using simple linear regression analysis technique by employing Statistical Package for the Social Sciences (SPSS) version 21. Result of data analysis revealed a significant negative effect of teachers' stress on their job performance in the elementary schools of Southern Papua. It means that the lower teachers' stress the higher teachers' job performance, the higher teachers' stress the lower teachers' job performance. Finding of this study may theoretically contribute a valuable extension of the existing researches as it gives an insight into the stress and job performance of elementary school teachers who survive in the challenging context of Southern Papua, Indonesia.
\end{abstract}

Keywords Performance, Stress, Teacher, Elementary Schools, Southern Papua

\section{Introduction}

Teachers are the foundation stone for developing and advancing the construction of any society and of nation alike, and they aspire for working in conducive atmosphere that enables teachers to do more than what are required from them [1]. Poor working conditions facing the elementary school teachers of Southern Papua, as it was indicated by Wea et al. [2] may impose stress on teachers individually. Though there has been a brilliant effort of
Indonesian Government to recognize and to appreciate the hard-work of a teacher by doubling a teacher's take home pay, teaching remains a very stressful profession for those teachers who are working in the remote elementary schools of Southern Papua [3-4].

Job stress is a major problem for organization and individual alike [5]. Job stress is a common work-place problems facing all the professionals irrespective of their nature of work [6]. Hans Hugo Bruno Selye (1907-1982) was the first to use the word stress in the context of biomedicine. Selye [7] viewed stress as the non-specific response of body, either positive or negative, to any demand. Selye [7] asserted that stress is not necessarily something bad or something to be avoided because "success can be beneficial where that of illness or failure can be detrimental" [8]. In this point of view, a certain amount of stress is needed to motivate individuals into action or helping one to remain productive and challenged at work.

Since 1956, a growing amount of studies have been conducted on this topic and the idea of stress has also moved from a "both good and bad thing" to "a bad thing" with a range of harmful and long-term effect. Not surprisingly if Selye $[9,66]$ viewed stress as "the state manifested by a specific syndrome which consists of all the nonspecifically induced changes within a biologic system", while [10] viewed stress as a person's adaptive response to a stimulus that places excessive psychological or physical demand on that person. Whereas Nair [6] viewed stress as unpleasant state of emotional arousal that a person experiences in situations that he/she perceives as dangerous or threatening. Despite of no definition of stress has been universally accepted, what is consistent in the literature is that feeling experienced when a person perceives that demands of the work-environment exceed the personal and social resources. Although job stress is not a disease, prolonged stress can have a huge impact on overall health such as asthma, high blood pressure, mood 
and sleep disturbances, headaches, and fatigue [6] and produce a negative impact on performance [11].

Paulse [12] classified the sources of stress into several groups as follows: (a) stress related to organizational factors such as organizational structure, climate, and leadership; (b) task demands such as working conditions and overtime; (c) stress related to the role of organization such role overload and responsibility, role ambiguity, and role conflict; (d) stress related to individual factors such as negative affectivity and self-efficacy; and (e) stress related to extra-organization such as social support. While Nair [6] pointed out numerous sources of stress as follows: (a) heavy workload, (b) unpleasant work practices, (c) work pressure, (d) management techniques and approaches, (e) work environment, (f) no clear job descriptions or career prospects, (g) lack of support from superiors and non-cooperation of subordinates, (h) lack of participation in decision-making, (i) heavy responsibility without sufficient authority and decision-making power, (j) time deadlines to finish the work, $(\mathrm{k})$ inadequate time to attain the target, (l) lack of recognition or reward for better performance, and (m) absence of grievance redress mechanism. Whereas Health Safety Executive [13, 3] identified six management standards to cover six main sources of job-stress as follows: (a) demands: referring to workload, work pattern, and work environment; (b) control: referring to whether a person has a say in the way he/she does his/her work; (c) support: referring to the encouragement, sponsorship, and resources provided by the organization, the supervisors, and the colleagues; (d) role: referring to whether all the employees understand their roles and whether the organization ensures that they do not have conflicting roles; and (e) change: referring to how organizational change (large or small) is managed and communicated within the organization; and (f) relationships: referring to the effort of promoting positive work and of avoiding conflict and unacceptable behavior.

Job stress has long been recognized as one of the prevalent contributor factors to employees' performance, either positively or negatively [7, 11, 14-19]. Job performance is the observable behavior that employees do in their work that are relevant to the goals of an organization [20]. Job performance of employees is of the most critical subject for organizational outcomes and success. There are various definition of job performance. Henry and Jenkins [21], for example viewed job performance as an activity in which an employee is able to successfully accomplish a given task subject to the normal constrains of reasonable utilization of the available resources. Meanwhile Motowidlo et al. [22] viewed job performance as the aggregated value to the organization of the discrete behavioral episodes that an individual performs over an established period of time. Whereas Mathis and Jackson [23] opined that performance is associated with the quantity and quality of output, timeliness of output, attendance at work, efficiency and effectiveness of the work completed.
Despite of no universal agreement on the concept of job performance, what is consistent in the literature is that the activity in which a person is able to successfully accomplish the assigned task. Borman and Motowidlo [24] classified performance into two dimensions, namely task performance and contextual performance, which distinguishes between behavior that directly related to the job and behavior that contribute to organization outcomes in ways that are not related directly to the core job functions [25] . Borman and Motowidlo [26] pointed out three basic assumptions related to the differentiation between task and contextual performance as follows: (a) activities relevant to task performance vary between jobs, while contextual performance activities are relatively similar across jobs; (b) task performance is related to ability, while contextual performance is related to personality and motivation; and (c) task performance is more prescribed and constitutes in-role behavior, while contextual performance is more discretionary and extra-role.

Task performance refers to the core technical behaviors and activities involved in a particular job. All core technical behaviors in task performance are tightly regulated. Each element of task performance has a specified minimum level of performance and there are standardized management procedures for the employees who fail to perform any of these behaviors at the required standards [27]. Campbell et al. [20] indicated that among the eight performance components proposed by Campbell in 1990, five components of which refer to task performance. These five components are follows: (a) job-specific task proficiency; (b) non-job-specific task proficiency; (c) written and oral communication proficiency; (d) supervision - in the case of a supervisory or leadership position - and (e) management/ administration [28]. Examples of task performance are performing communication task, maintaining good working relationship, and operating facilities.

Contextual performance refers to behaviors (such as helping coworkers and defending the organization) that support the environment in which the technical core operates. Different from task performance, contextual performance is not regulated because there is no minimum standard required for each behavior [27]. Contextual performance was grouped by Sonentag and Freze [28, 6-7] into two broad categories as follows: (a) behaviors which aim primarily at the smooth functioning of a particular organization as it is at the present moment, and (b) proactive behaviors which aim primarily at changing and improving work procedures and organizational processes. Examples of contextual performance are demonstrating extra effort, following organization rules and procedures, assisting and coordinating with others, and alerting colleagues about work-related problems [23] [26].

A growing amount of studies [29-32] have proved that task and contextual performance cannot only be conceptually distinguished, but also empirically separated. 
For instance abilities and skills tend to predict task performance, while personality and related factors tend to predict contextual performance [24] [33]. Borman et al. [34] found that personality correlates more highly with organizational citizenship behaviors than with task performance, while Jenkins and Griffith [35] argued that when the personality variables used to predict job performance derived from job analysis, they predict task-related performance and contextual performance as well.

The term 'stress' here refers to teachers' work-related stress. Bakare [36] referred to teaching as one of the most stressful profession compare to others such as police force, fire brigade, and nursing. Robinson [37] argued that teachers stress is almost as varied as the individuals themselves and most of stress are manifested in one of the following three ways: attitude, physical well-being, or performance [37]. Kyriacou and Chien [38] posited that sources of stress facing a particular teacher are unique, depend on the precise complex interaction between the teacher's personality, values, skills, and circumstances.

As aforementioned, teachers stress has long been widely recognized as link to teaching performance [39-50]. Therefore, it is essential for this study to closely measure the effect of teachers' stress on their job performance in the elementary schools of Southern Papua. We are inspired to investigate the topic in order to address the regional need of having qualified elementary school graduates in Southern Papua, Indonesia. Despite the possibility of conclusion similarity of this study with the previous ones, result of this study may hypothetically contribute to the existing body of knowledge as it offers a first look on this topic within the context of Southern Papua, Indonesia.

Based on the beliefs of the poor performance of elementary school teachers of Southern Papua as the main cause of students' incapability in reading, writing, and arithmetic [51], this study focuses on the effort of investigating work-related stress of elementary school teacher of Southern Papua, Indonesia, as one of predicting factors for their performance. To do so, we employed a quantitative research approach by utilizing two survey questionnaire as the main tools for gathering data as we will briefly explain below.

\section{Methods}

This investigation employed a quantitative approach using survey study to describe work-related stress of elementary school teachers of Southern Papua and its prospective effect on their job performance. Survey questionnaires were used based on the following six advantages: (a) low cost, (b) precise results, (c) high representativeness, (d) convenient data gathering, (e) good statistical significance; and (f) little researchers' subjectivity [52].

A self-administered survey questionnaires using a four-point Likert's scale was used to gather research data from a total number of 1062 teacher respondents which were incidentally drawn from amongst 3078 elementary schools' teachers of Southern Papua due to that of most of the elementary schools are located in hinterland and, therefore, are difficult to reach (see Table 1).

Table 1. Details of Geographical and Astronomic Position of Southern Papua

\begin{tabular}{|c|c|c|c|c|c|c|}
\hline No. & District & Area & Astronomic Position & $\begin{array}{c}\text { Number of } \\
\text { Schools }\end{array}$ & $\begin{array}{c}\text { Number of } \\
\text { Teachers }\end{array}$ & $\begin{array}{c}\text { Number of } \\
\text { Samples }\end{array}$ \\
\hline 1. & Asmat & $\begin{array}{l}29,658 \mathrm{~km}^{2} \\
\text { (Hinterland) }\end{array}$ & $\begin{array}{l}1370-1400 \\
\text { East Longitude } \\
040-070 \\
\text { South Latitude }\end{array}$ & 117 & 762 & 7 \\
\hline 2. & Boven Digoel & $\begin{array}{c}27,836.68 \mathrm{~km}^{2} \\
\text { (Hinterland) }\end{array}$ & $\begin{array}{c}139090^{\prime}-1410 \\
\text { East Longitude } \\
04098^{\prime}-07010^{\prime} \text { South } \\
\text { Latitude }\end{array}$ & 81 & 412 & 352 \\
\hline 3. & Mappi & $\begin{array}{l}28,518 \mathrm{~km}^{2} \\
\text { (Hinterland) }\end{array}$ & $\begin{array}{c}137029^{\prime}-139052^{\prime} \text { East } \\
\text { Longitude } \\
0404^{\prime}-09002^{\prime} \\
\text { South Latitude }\end{array}$ & 151 & 264 & 53 \\
\hline 4. & Merauke & $45,071 \mathrm{~km}^{2}$ & $\begin{array}{c}1370-1410 \\
\text { East Longitude } \\
060-090 \\
\text { South Latitude }\end{array}$ & 203 & 1300 & 648 \\
\hline 5 & Yahukimo & $\begin{array}{c}17,152 \mathrm{~km}^{2} \\
\text { (Hinterland) }\end{array}$ & 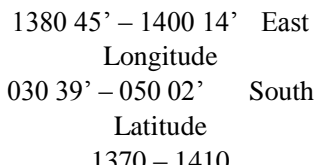 & 91 & 340 & 2 \\
\hline & Total & $148,24.68 \mathrm{~km}^{2}$ & $\begin{array}{c}\text { East Longitude } \\
030 \text { 39' }-090 \\
\text { South Latitude }\end{array}$ & 643 & 3078 & 1062 \\
\hline
\end{tabular}

Adopted from Werang et al. [4] with modification 
Research data were statistically examined using simple linear regression analysis technique by employing the Statistical Package for the Social Sciences (SPSS) version 21. One research hypothesis $\left(\mathrm{H}_{\mathrm{a}}\right)$ was proposed to be examined that is teachers' stress will significant negatively effect on their job performance in the elementary schools of Southern Papua. This hypothesis was tested using the coefficient value of alpha $(\alpha)=.05$ or the confidence level of $95 \%$.

The teachers' job performance was measured using questionnaire items from a study conducted by Wolomasi et al. [53]. This variable was measured using 15 items of questionnaire, scored from 1 (Strongly Disagree) to 4 (Strongly Agree). An Indonesian language version of the questionnaire was self-administered to the total number of 1062 elementary school teachers who have incidentally been established as respondents. All teacher-respondents were asked to respond each item of questionnaires on a four-point Likert's scale, that are 'Strongly Disagree' (SD), 'Disagree' (D), 'Agree (A), and Strongly Agree' (SA). Sample of the English version of items are follows: "I help students improve their learning process and class improvement", "I prepare teaching materials at the beginning of the school year", "I evaluate students work diligently", "I personally provide learning media which are not provided by the school", "I use diverse learning media to teach for understanding", "I use diverse learning method and strategies to teach for understanding", "I always take an opportunity to participate in education conferences or seminars to upgrade knowledge and skills", and "I give chance for students to lead the class-discussion".

Teachers' stress was measured by modifying items of questionnaires developed by Kyriacou and Chien [38]. This variable was measured using 9 items of questionnaire, scored from 1 (No Stress) to 4 (Extreme Stress). An Indonesian language version of the questionnaire were self-administered to the total number of 1062 elementary school teachers who have incidentally been established as respondents. All respondents were asked to respond each item of questionnaires on a four-point Likert's scale, that are 'No Stress' (NS), 'Little Stress' (LS), 'A Lot of Stress' (ALoS), and 'Extreme Stress' (ES). Sample of the English version of items are follows: "Changeable education curriculum and policy of the government", "Parents' unawareness on the importance of education", "Poor working conditions", "Management style of the school principal", "Not enough teaching resources", "Students who lack motivation".

\section{Result and Discussion}

In nowadays community where industrialization and technology become an integrating part of one's life, being a teacher is extremely stressful comparing to other professions or jobs [38,54-56]. Nowadays teachers are being constantly bombarded with many tasks and responsibilities [37], inside or outside the classroom. These tasks and responsibilities may lead to a chronic stress. When high demands of communities and stress are combined then the poor teacher performance will increase.

This study attempted to analyze work-related stress and job performance among elementary schools' teachers of Southern Papua. The independent variable in this case was teachers' work-related stress and the dependent variable was teachers' performance. The effect of these two variables was analyzed using the simple linear regression analysis technique by employing the Statistical Package for Social Sciences (SPSS) version 21.

Data in Table 2 revealed a significant negative effect of teachers' stress on job performance in the elementary schools of Southern Papua. As, at the level of alpha $(\alpha)$ $=.05$, the coefficient value of beta $(\beta)$ is -.864 and the significant value is .000 then the research hypothesis that teachers' stress will significant negatively effect on their job performance in the elementary schools of Southern Papua is accepted.

Table 2. The effect of Teacher Stress on Their Job Performance $(\mathrm{N}=$ 1062)

\begin{tabular}{|c|c|c|c|c|c|c|}
\hline & \multirow[t]{2}{*}{ Model } & \multicolumn{2}{|c|}{$\begin{array}{c}\text { Unstandardized } \\
\text { Coefficients }\end{array}$} & \multirow{2}{*}{$\begin{array}{c}\begin{array}{c}\text { Standardized } \\
\text { Coefficients }\end{array} \\
\text { Beta }\end{array}$} & \multirow[t]{2}{*}{$\mathrm{t}$} & \multirow[t]{2}{*}{ Sig. } \\
\hline & & B & $\begin{array}{l}\text { Std. } \\
\text { Error }\end{array}$ & & & \\
\hline \multirow[t]{2}{*}{1} & (Constant) & 72.684 & .348 & & 208.603 & .000 \\
\hline & STRESS & -.799 & .014 & -.864 & -55.852 & .000 \\
\hline
\end{tabular}

a. Predictor: (Constant) STRESS

b. Dependent Variable: PERFORMANCE

As the coefficient value of beta $(\beta)$ is negative means that for every point decrease in teachers' stress will increase 0.864 point in teachers' job performance in the elementary schools of Southern Papua. In reverse, for every point increase in teachers' stress will decrease 0.864 point in teachers' job performance in the elementary schools of Southern Papua. It inferred that teachers' job performance in the elementary schools of Southern Papua can be attributed to teachers' stress. Finding of the study suggests that there are other variables outside the focus which also contribute to the level of stress facing the elementary schools' teachers of Southern Papua.

When teacher absenteeism, turnover, and worse performance are recognized as indicators of teachers' chronic stress then we have to say that most teachers in the elementary schools of Southern Papua work under stress as Werang et al. [4] and Werang et al. [51] indicated that one in three teachers were absent and engaging with other attractive activities for a long period of time. In fact, most elementary schools' teachers in Southern Papua work in dilapidated buildings without the necessary learning resources, inadequate school-housings, lack of electricity 
and internet facilities, lack of support and assistance from both administrators and colleagues, and lack of local communities' ties. Parents' hostility facing the elementary schools' teachers in several areas of Southern Papua, for example, told us much of how low the local communities' ties are.

Anderson [57] argued that teacher effectiveness is a strong determinant for school effectiveness and students' success, whereas teacher stress is a strong determinant for school ineffectiveness and student failure because chronic stress can reduce teachers' ability to perform at the highest levels. Farber [58] noted that chronic stress that accompanies teaching can compromise and damage high quality educational practices that should be consistently applied in school today. In this point of view, teachers will go more productive and, therefore, tend to do more than what are required if they are able to cope stress they experienced. Conversely, teacher will grow more unproductive and tend to do less than what are required if they are not able to deal with stress. If it is so, teachers' instruction will suffer which then impacts student well-being and academic achievement [59].

Teachers in Southern Papua, in fact, have adequate ways of coping with their work-related stress by either spending sometimes being alone and praying to God or by accepting the situation and ignoring the problems at once. What is noteworthy is that teacher-respondents would never turn to drinking alcohol nor take drugs during their time of stress. Keeping on the view of teachers' capability of coping with stress, studies in the United States, England, Germany, and Canada indicate that school principals are a key factor in heightening or lowering teacher stress [60]. The reason is that most work-related stress experienced by teachers can be traced to school principals [61].

Werang [62] posited that teachers will feel comfortable when they work under a sympathetic caring leader and, therefore, it is necessary for the school principals to recognized and to treat their staff fairly and sympathetic. Black [63] asserted that principals who offered their strong social support provided a buffer that helps teachers' work-related stress, while Marshall [60] argued that school principals who communicates a clear vision for the school and had a close and personal relationship with their staff were found to have the lowest teacher stress. Marshall [60] further stated that allowing time for teachers to collaborate, providing more support for teachers, building a better communication with teachers, and providing more praise/respect for the job are simple activities, among others, that school principals might do to help relieve teacher stress. The more teachers trust in principals' paramount effort of creating a healthy and supportive school environment the lower stress [59].

\section{Conclusions}

This study was meant to describe the potential effect of teachers' work-related stress on their job performance in the elementary schools of Southern Papua. Based on the result of data analysis as it was previously discussed, this study reaches the following conclusion: teachers' work-related stress has a significant negative effect on their job performance in the elementary schools of Southern Papua. In other words, teachers' job performance in the elementary schools of Southern Papua can be predicted by their work-related stress as the coefficient value of beta $(\beta)$ $=-.864$ is significant at the level of alpha $(\alpha)=.05$.

Finding of this study may theoretically contribute a valuable extension of other previous studies as it gives an insight to the stress and job performance of elementary school teachers who strive in the challenging context of Southern Papua, Indonesia. Practical implication of this study is that school principals should make a paramount effort of creating a healthy and supportive school environment for both teachers and students. When teachers are under considerable stress from rapidly change of duties and responsibilities both inside and outside the classroom, it is arguably that the whole students will suffer from it. As good teachers do their work at the highest level in schools with good leadership, a school principal who is both mentally and physically unwell could have a potentially dreadful effect on the well-being of both teachers and students. In this point of view, high teacher trust in principals' support will help teachers to cope with stress and, in turn, students' rights to success are adequately addressed.

The result of this study must be cautiously interpreted due to that of limited coverage area and small sample size. Finding of this study, therefore, cannot be generalized for the whole part of Indonesia. In order to generalize the findings, a further study with a wider range of area and a greater size of samples will be fully recommended.

\section{REFERENCES}

[1] M. N. Gharib, S. A. Jamil, M. Ahmad, S. Ghouse, S. The impact of job stress on job performance: A case study on academic staff at Dhofar university, International Journal of Economic Research, Vol. 13, No. 1, 21-33, 2016.

[2] D. Wea, B. R. Werang, O. Irianto, H.P. Asmaningrum. The effect of teachers' working conditions on job performance in remote elementary schools of Indonesia: Teachers' perceptions. Current Issues in Education, in print.

[3] B. R. Werang. The effect of workload, individual characteristics, and school climate on teachers' emotional exhaustion in elementary schools of Papua, Cakrawala Pendidikan, Vol. 37, No. 3, 457-469, 2018. doi: https://doi.org/10.21831/cp. v38i3.20635.

[4] B. R. Werang, A. A. G. Agung, A. A. Hurit. Increasing teacher attendance in Indonesia: A longitudinal study in the remote elementary schools of Southern Papua, International Journal of Management in Education, Vol. 13, No. 2, 133-155, 2019. doi: https://doi. org/10.1504/IJMIE.2019.10018032. 
[5] C. S. Leong, A. Furnham, C. L. Cooper. The moderating effect of organizational commitment on the occupational stress outcome relationship, Human Relations, Vol. 49, 1345-1363, 1996.

[6] D. G. Nair. An analytical study on occupational stress among bank employees in Kerala, A Thesis presented to the Mahatma Gandhi University, Kottayam, 2013. Online available

from: http://shodhganga.inflibnet.ac.in/handle/ 10603/28497

[7] H. Selye. The Stress of Life, McGraw-Hill, New York, 1956.

[8] E. D. Raleigh. (1980). The Stress Response. Online available from: https://journals. sagepub.com/doi/pdf/10.1177/216507998002801202

[9] H. Selye. Stress in Health and Disease, Butterworth, Boston, 1976.

[10] H. Moorhead, F. Griffin. Organizational Behavior, Houghton Mifflin Company, Boston, 1998.

[11] D. Hellriegel, J. W. Slocum, R. W. Woodman. Organizational Behavior, South-Western College Publishing, Cincinnati, 2001.

[12] J. Paulse. Sources of Occupational Stress for Teachers, with Specific Reference to the Inclusive Education Model in the Western Cape. Master's Thesis presented to the Faculty of Economic and Management Sciences, University of the Western Cape, 2005. Online available from: etd.uwc.ac.za/xmlui/bitstream/handle/.../Paulse_ MA_2005.p...

[13] Health Safety Executive. How to Tackle Work-Related Stress: A Guide for Employers on Making the Management Standards Work, 2009. Online available from: http:// www.hse.gov.uk/pubns/indg430.pdf

[14] A. Ahmed, M. Ramzan, M. Effect of job stress on employees' job performance: A study on banking sector of Pakistan, IOSR Journal of Business and Management, Vol. 11, No. 6, 61-68, 2013.

[15] U. Bashir, M. I. Ramay. Impact of stress on employees job performance. A study on banking sector of Pakistan, International Journal of Marketing Studies, Vol. 2, No. 1, 122-126, 2010.

[16] M. H. Hassan. (2014). The relationship between stress and work performance of police officer in Kasarani Sub County, A thesis presented to the University of Nairobi, 2014. Online available from: erepository.uonbi.ac.ke/.../Hassan_\%20 The\%20 relationship.

[17] N. K. Khuong, V. H. Yen. Investigate the effects of job stress on job performance-A case study at Dong Xuyen industrial zone, Vietnam, International Journal of Trade, Economics, and Finance, Vol. 7, No. 2, 31-37, 2016.

[18] O. L. Siu. (2003). Job stress and job performance among employees in Hongkong: The role of Chinese work values and organizational commitment, International Journal of Psychology, Vol. 38, No. 6, 337-347, 2003. doi: 10.1080/00207590344000024.

[19] C. Fonkeng. Effect of Job-Stress on Employee Performance in an Enterprise. A thesis presented to the Centria University of Applied Sciences, 2018. Online available from: www.theseus.fi/handle/10024/145790.

[20] J. P. Campbell, M. B. Gasser, F. L. Oswald. The substantive nature of job performance variability. In K. R. Murphy (Ed.), Individual Differences and Behavior in Organizations (pp. 258-299), Jossey-Bass, San Francisco, CA, 1996.

[21] C. Hendry, R. Jenkins. (1998). Psychological contracts and new deals, Human Resources Management Journal, Vol. 7, 38-43. 1998.

[22] S. J. Motowidlo, W. C. Borman, M. J. Schmitt. A theory of individual differences in task and contextual performance, Human Performance, Vol. 10, No. 2, 71-83, 1997.

[23] W. C. Borman, S. J. Motowidlo. Expanding the criterion domain to include elements of contextual performance, in $\mathrm{N}$. Schmitt \& W. C. Borman (Eds.), Personnel Selection in Organizations (pp.71-98), Jossey-Bass, San Francisco, CA, 1993.

[24] R. L. Mathis, J. H. Jackson. Human Resources Management. South-Western Cengage Learning, Mason, USA, 2009.

[25] U.W.M.R.S. Kappagoda. Self-efficacy, task performance and contextual performance: A Sri Lankan experience, Journal of Human Resource and Sustainability Studies, Vol. 6, 157-166, 2018.

[26] W. C. Borman, S. J. Motowidlo. Task performance and contextual performance: the meaning for personnel selection research, Human Performance, Vol. 10, 99-109, 1997.

[27] M. Griffin, A. Neal, M. Neale. The contribution of task performance and contextual performance to effectiveness: Investigating the role of situational constrains, Applied Psychology, Vol. 49, No. 3, 517-533, 2001.

[28] S. Sonentag, M. Freze. Performance Concept and Performance Theory, 2002. Online available from: https://www.researchgate.net/.. Performance_C

[29] E. W. Morrison, C.C. Phelps. Taking charge at work: Extra role efforts to initiate workplace change, Academy of Management Journal, Vol. 42, 403-419, 1999.

[30] S. J. Motowidlo, J. R. Van Scotter. Evidence that task performance should be distinguished from contextual performance, Journal of Applied Psychology, Vol. 79, 475-480, 1994.

[31] J. R. Van Scotter, S. J. Motowidlo. Interpersonal facilitation and job dedication as separate facets of contextual performance, Journal of Applied Psychology, Vol. 81, 525-531, 1996.

[32] L. J. Williams, S. E. Anderson. Job satisfaction and organizational commitment as predictors of organizational citizenship and in-role behaviors, Journal of Management, Vol. 17, 601-617, 1991.

[33] K. Hattrup, M. S. O'Connel, P. H. Wingate. Prediction of multidimensional criteria: Distinguishing task and contextual performance, Human Performance, Vol. 11, 305-319, 1998.

[34] W. C. Borman, L. A. Pener, T. D. Allen, S. J. Motowidlo. Personality predictors of citizenship performance, International Journal of Selection and Assessment, Vol. 9, No. 1-2, 52-69, 2001.

[35] M. Jenkins, R. Griffith. Using personality constructs to predict performance: Narrow or broad bandwidth, Journal of Business and Psychology, Vol. 19, No. 2, 255-269, 2004. 
[36] C. A. Bakare. The dynamic of psychological stressors and management of human stress, Human Resources Journal, Vol. 1, No. 2, 104-112, 2005.

[37] J. P. Robinson. Teacher stress: Causes, stages, and effect, Journal of Health Occupations Education, Vol. 4, No. 1, 68-80, 1989.

[38] C. Kyriacou, P. Y. Chien. Teacher stress in Taiwanese primary schools, Journal of Educational Enquiry, Vol. 5, No. 2, 86-104, 2004.

[39] S. Anandasayanan, V. A. Subramaniam. Effect of Stress on Teachers' Performance with Special Reference to Jafna District Schools, 2013. Online available from: https:// papers.ssrn.com/sol3/Delivery.cfm/SSRN_ID2386067_cod e218826 4.pdf?..

[40] M. K. Gitonga, J. M. Ndagi. Influence of occupational stress on teachers' performance in public secondary schools in Nyeri County, Nyeri South Sub County Kenya, International Journal of Business and Management Invention, Vol. 5, No. 5, 23-29, 2016.

[41] N. Laily, D. U. Wahyuni. Teacher performance based on stress on organizational commitment, International Journal of Scientific and Research Publication, Vol. 7, No. 12, 192-199, 2017.

[42] D. S. Ngina. (2013). Effect of Stress on Academic Performance among Public Secondary School Teachers in Kathiani District, Kenya. Online available from: https://erepository.mku.ac.ke/handle/123456789/2264

[43] M. F. Wangui, K. Ombui, M. Iravo. Effects of work-related stress on teachers' performance in public secondary schools in Kikuyu Sub County, Kenya, International Journal of Science and Research, Vol. 5, No. 5, 1645-1652, 2016.

[44] F. A. Yusuf, Y. R. Olufunke, M. D. Valentine. Causes and impact of stress on teachers' productivity as expressed by primary school teachers in Nigeria. Creative Education, Vol. 6, 1937-1942, 2015.

[45] M. Alkubaisi. How can stress affect your work performance? Quantitative field study on Qatari banking sector, Business and Management Research, Vol. 4., No. 1, 99-109, 2015.

[46] Aulia. Stress kerja dan kinerja, Humanitas, Vol. 13, No. 2, 95-111, 2017.

[47] I. M. Awadh, L. Gichinga, A. H. Ahmed. Effect of workplace stress on employee performance in the county governments in Kenya: A case study of Kilifi county government, International Journal of Scientific and Research Publications, Vol. 5, No. 10, 1-8, 2015.

[48] L. Dar, A. Akhmal, M. A. Naseem, K. U. D. Khan. Impact of stress on employees job performance in business sector of Pakistan, Global Journal of Management and Business Research, Vol. 11, No. 6, 1-4, 2011.

[49] G. Fink. (2017). Stress: Definition and History, 2017. Online available from: https://www.researchgate.net/publication/285784528_Stres s_Definition_and_history.

[50] K. P. Nyangahu, H. O. Bula. Relationship between work stress and performance of employee: A case study of transit hotel in Nairobi city county, Archieves of Business Research, Vol. 3, No. 6, 22-37, 2015.

[51] B. R. Werang, S. M. R. Leba, E. A. G. Pure. Factors influencing teacher absenteeism in the remote elementary schools of Indonesia: Empirical proof from Southern Papua. International Journal of Management in Education, Vol. 11, No. 3, 223-247, 2017. doi: 10.1504/IJMIE.2017.084923.

[52] B. R. Werang, A. A. G. Agung, A. A. Hurit. School principal's leadership, teacher's organizational commitment, and teacher's morale in the elementary schools of Papua: teachers' perspective, Cakrawala Pendidikan, in print.

[53] A. K. Wolomasi, S. I. Asaloei, B. R. Werang. (2019). Job Satisfaction and Performance of Elementary School Teachers, International Journal of Evaluation and Research in Education, Vol. 8, No. 4, 575-580, 2019. DOI: 10.11591/ijere.v8i4.20264.

[54] O. Clipa. Stress factors and solutions for the phenomenon of burnout of preschool teachers, Procedia-Social and Behavioral Sciences, Vol. 80, 916-923, 2015.

[55] O. Clipa. Teacher stress and coping strategies, in O. Clipa (ed.), Studies and Current Trends in Science of Education (pp. 120-128), LUMEN Proceedings, Suceava, Romania, 2017.

[56] A. A.Ignat, O. Clipa. Teachers' satisfaction with life, job satisfaction and their emotional intelligence, Procedia-Social and Behavioral Sciences, Vol. 33, 498-502, 2012.

[57] L. W. Anderson. Increasing Teacher Effectiveness, International Institute for Educational Planning, Unesco, 2004.

[58] B. A. Farber. (1984). Stress and burnout in suburban teachers, The Journal of Educational Research, Vol. 77, No. 6, 325-331, 1984.

[59] M. T. Greenberg, J. L. Brown, R. M. Abenavoli. (2016). Teacher Stress and Health Effects on Teachers, Edna Bennett Pierce Prevention Research Center, Pennsylvania State University, 2016.

[60] I. A. Marshall. Principal leadership style and teacher stress among a sample of secondary school teachers in Barbados, Caribbean Educational Research Journal, Vol. 3, No. 1, 76-90, 2015.

[61] A. Harris. The relationship between principal leadership styles and teacher stress in low socio-economic urban elementary schools, Dissertation Abstracts International, Vol. 58, 2863, 1999.

[62] B. R. Werang. A study of relationships in Christian primary schools of Boven Digoel regency, Papua, Indonesia, The International of Educational Organization and Leadership, Vol. 22, No. 2, 25-32, 2015. doi: https://doi.org/10.18848/23291656/CGP/ v22i02/48502

[63] S. Black. Stressed out in the classroom, American School Board Journal, Vol. 190, No. 10, 36-38, 2003. 